Advance Journal of Food Science and Technology 17(2): 18-27, 2019

DOI:10.19026/ajfst.17.5998

ISSN: 2042-4868; e-ISSN: 2042-4876

(C) 2019 Maxwell Scientific Publication Corp.

Submitted: November 08, 2018

Accepted: December 27, 2018

Published: March 25, 2019

\title{
Research Article \\ Supply Chain Risk Mitigation of Enting Geti with Fuzzy Failure Mode and Effect Analysis and Analytical Hierarchy Process (Case Study at Small Medium Enterprises of Kuda Terbang, Blitar District, East Java Province, Indonesia)
}

\author{
${ }^{1,2}$ Siti Asmaul Mustaniroh, ${ }^{1}$ Dania Radyarini and ${ }^{1,2}$ Rizky Luthfian Ramadhan Silalahi \\ ${ }^{1}$ Department of Agroindustrial Technology, Faculty of Agricultural Technology, \\ ${ }^{2}$ Research Group of Creative Agroindustry, Universitas Brawijaya, Malang, Indonesia
}

\begin{abstract}
The aim of study are to identify, measure and assess supply chain risks and to determine strategy alternatives to reduce the risk of supply chains at SMEs Kuda Terbang. SMEs Kuda Terbang is one of the business entities producing enting geti in the center of enting geti production in Kademangan, Blitar regency. Problems that occur in the supply chain are low availability of raw materials, production equipment using traditional equipment and fluctuating market demand. The method used in this study is Fuzzy FMEA and AHP. Variables used in this study were ingredients, production and products. Expert respondents used in this study amounted to 6 people for supply chain risk assessment and 2 persons for the determination of supply chain risk mitigation strategies consisting of suppliers, companies, retailers and academics. The risks identified in the ingredients variables are 4 risks, 7 risks on the production variable and 5 risks on the product variables. The highest risk in ingredients variable is the fluctuating ingredients prices (FRPN of 5.67), in production variable is the uncertain production schedule (FRPN of 6.87) and in product variable is the product return (FRPN of 6.83). The priority strategy of supply chain risk mitigation of enting geti at SMEs Kuda Terbang is the quality control with the weight of 0.35 .
\end{abstract}

Keywords: Enting genti, Fuzzy FMEA, risk mitigation, supply chain

\section{INTRODUCTION}

Blitar Regency is one of the food producing regions in East Java, Indonesia and has a role in strengthening food security. One type of food crop that is widely produced in Blitar Regency is peanuts. Based on data from Blitar District in Figures, average peanut production in 2014 was 11.47 quintals per hectare. The famous peanut food products in Blitar Regency are important. Enting geti is a typical food of Blitar Regency made from peanuts, sugar and sesame. The production capacity of SMEs Kuda Terbang is 2 quintals which is important in every production. One of the efforts made so that the raw material needed and the desired product can always be available at SMEs Kuda Terbang, is to manage the parties involved in the supply chain system. The product supply chain is an activity that starts from raw materials to after-sales handling.

Supply chain management according to Stadtler (2008), is an act of sharing information, material and financial information in organizational units, so as to meet customer needs and increase supply chain integrations. Supply chain management is goods, information and financial management through a network of organizations such as suppliers, producers, logistics providers, wholesalers/distributors, retailers who aim to produce and deliver products or services to consumers (Tang, 2006). Felea and Albăstroiu (2013) stated that, supply chains including producers, suppliers, transporters, warehouses, wholesalers, retailers to customers. The implementation of supply chain activities always pose risks that can harm the company. Risk management is a business that is rationally aimed at reducing the likelihood of losses from the risks faced. Several reasons are behind this development:

- Globalization has made supply chains longer and more complex; consequently, supply chains are now exposed to more risks and have become more vulnerable.

- The lean management philosophy has become widely implemented in many industries; this philosophy advocates waste elimination/minimization and embraces just-intime production/logistic; although it improves

\footnotetext{
Corresponding Author: Siti Asmaul Mustaniroh, Department of Agroindustrial Technology, Faculty of Agricultural Technology, Universitas Brawijaya, Jl. Veteran, Malang, East Java Province, Indonesia, Tel.: +62341583964 ; Fax: +62341583964

This work is licensed under a Creative Commons Attribution 4.0 International License (URL: http://creativecommons.org/licenses/by/4.0/).
} 
supply chain efficiency, the removal/reduction of redundancies has resulted in greater supply chain vulnerability under adverse events.

- The world has paid increasing attention to the many supply chain disruptions that have been caused by catastrophic events (Behzadi et al., 2018). Recent changes and developments, especially in economis and supply chain, resulted in increasing uncertainties. Along with the increasing number of relevant uncertainties, the importance assigned to risk considerations has grown (Heckmann et al., 2015). According to Aishah et al. (2013) integration in the internal supply chain needs to be done. This is because the internal supply chain provides the greatest impact on supply chain activities.

The problem that occurs in the supply chain at SMEs Kuda Terbang is the availability of low raw materials, production equipment using traditional equipment and fluctuating market demand. This is mainly because the product of enting geti is one food product, which supply chain managers need to recognize the importance of managing supply chain risk, due to the perishable nature and short life cycle of products (Nakandala et al., 2017). Peanuts obtained from the market with a size must be in accordance with the milling machine used, otherwise it is not suitable then the production process cannot be carried out. Traditional equipment with uncertain temperature and time in the process of heating sugar can cause inappropriate product characteristics. SMEs Kuda Terbang has a range of markets in several regions in East Java, but with uncertain demand, it causes uncertainty in the production of essential oils. These problems can cause other risks that can interfere with the operational performance at SMEs Kuda Terbang. The purpose of this research was to identify, measure and assess supply chain risks and determine alternative strategies to reduce the risk of supply chains at SMEs Kuda Terbang.

The method that can be used for supply chain risk assessment in this study is Fuzzy Failure Mode and Effect Analysis (Fuzzy FMEA). FMEA is a technique used to identify and eliminate known failures to improve the reliability and security of complex systems (Stamatis, 1995). Roghanian and Fatemeh (2015) Fuzzy logic is a very appropriate method for risk assessment and to deal with uncertainty and obscurity in humans in decision making. AHP is a quantitative technique developed for cases that have various levels of (hierarchy) analysis. Balubaid and Alamoudi (2015), this method takes into account the priorities that meet the requirements of a series of alternatives given on a scale based on the judgment of the decision maker. The methods used in this study are expected to determine the risks that occur in the supply chain and provide recommendations for risk mitigation strategies at SMEs
Kuda Terbang. Insurance assessment on risk aims to calculate how often the risk arises (Ambekar et al., 2013).

\section{MATERIALS AND METHODS}

Supply chain risk identification is carried out to define the factors that will become the benchmark of research in related supply chain activities. Identification of risk of supply chain requirements in SMEs Kuda Terbang can be seen in Table 1 .

Respondents involved in this research are expert respondents, namely respondents who understand well about the supply chain activity at SMEs Kuda Terbang both, practically and in knowledge. Number of respondents involved can be seen in Table 2 .

In this study the type of tests used was the Face Validity and Content Validity. The validity of the display will evaluate the shape and appearance of the basis of the questionnaire, while content validity is more on evaluating technical matters related to the questions in the questionnaire to fit the purpose of measurement.

Supply Chain Risk Assessment was conducted with Fuzzy FMEA (Failure Mode and Effect Analysis). According to Wang et al. (2009) steps that can be used in assessing the factors of failure mode in FMEA in fuzzy form with the following stages:

a. Determination of the scale of severity, occurrence and detection based on the results of the questionnaire.

Table 1: Identification of risk of supply chain requirements in SMEs Kuda Terbang

\begin{tabular}{ll}
\hline Variable of risk & Item of risk \\
\hline Raw material & 1. Low availability of raw materials \\
& 2. Late supply of raw materials \\
& 3. Prices of raw materials are volatile \\
& 4. Raw materials are not according to \\
Production & 1. Damards \\
& 2. Contamination during processing \\
& 3. Uncertain production schedules \\
& 4. Fluctuating production capacity \\
& 5. Low quality products \\
Product & 6. Damage to packaging during storage \\
& 7. The diversity of product prices in one \\
& 1. Fenter \\
& 2. Competitors of similar products \\
& 3. Lack of product inventory \\
& 4. Delay in product delivery \\
& 5. Product returns \\
\hline
\end{tabular}

Table 2: Number of respondents

\begin{tabular}{ll}
\hline Variable & Number of respondents \\
\hline Raw material & 2 people (supplier) \\
& 1 people (labor) \\
Production & 1 people academics \\
& 1 people (labor in manufacturing) \\
& 1 people (labor in marketing) \\
Product & 1 people academics \\
& 1 people (retailer) \\
& 1 people (labor in marketing) \\
& 1 people academics \\
\hline
\end{tabular}




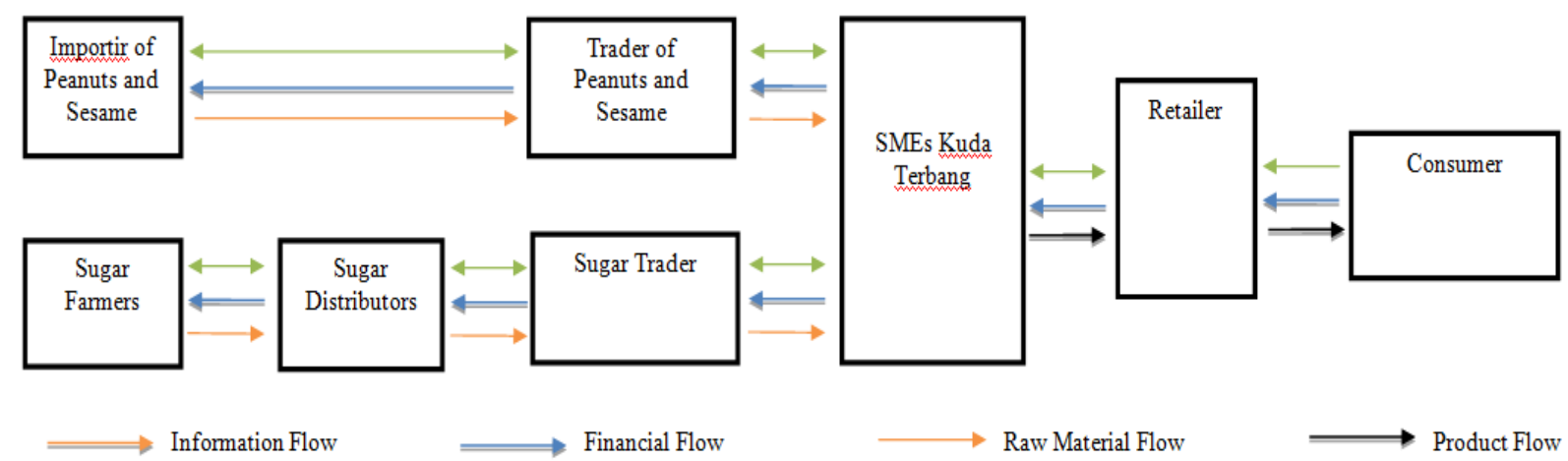

Fig. 1: Structure of supply chain for enting geti

b. Adjustment of S, O, D scale values to linguistic languages and fuzzy numbers

c. Conducting aggregation calculations for fuzzy rank assessments of factors $\mathrm{S}, \mathrm{O}, \mathrm{D}$.

d. Aggregate the importance weight for factor S, O, D.

e. Determine the FRPN for each risk with the following equation:

$\mathrm{FRPN}=\left(R_{i}^{S}\right) \frac{w^{S}}{w^{S}+w^{O}+w^{D}}+\left(R_{i}^{O}\right) \frac{w^{O}}{w^{S}+w^{O}+w^{D}}+\left(R_{i}^{D}\right) \frac{w^{D}}{w^{S}+w^{O}+w^{D}}$

FRPN: Fuzzy Risk Priority Number

$R_{i}^{S}$ : Aggregate value of S (severity)

$R_{i}^{O}$ : Aggregate value of O (occurrence)

$R_{i}^{D}$ : Aggregate value of $\mathrm{D}$ (detection)

$w^{S}$ : Aggregate value from Fuzzy S weight (severity)

$w^{o}$ : Aggregate value from Fuzzy $\mathrm{O}$ weight (Occurrence)

$w^{D}$ : Aggregate value from Fuzzy D weight (Detection)

f. Ranking based on FRPN values, where the biggest FRPN is the top rank.

Based on the FRPN value resulting from supply chain risk assessment, a mitigation strategy is determined to reduce the risks that occur in the supply chain at SMEs Kuda Terbang.

The stages of data analysis with AHP are:

a. Define the problem and determine the desired solution.

b. Create a hierarchical structure of the problems faced

c. Develop a pairwise comparison matrix that illustrates the influence of each element. A logical consistency test is the step of calculating the eigen matrix and maximum eigenvalues

\section{RESULTS AND DISCUSSION}

The food supply chain quality system is composed by the single processing enterprise and farmers, the farmers processing enterprises can provide Foods with the qualified rate enterprises for farmers, then the Foods that are under the detection standard can be rejected (Hornibrook and Fearne, 2003). SMEs Kuda Terbang is one of the important geti production businesses located in the center of geti production village in Rejowinangun Village, Kademangan, Blitar Regency. SMEs Kuda Terbang was founded by Mrs. Sulasmi in 1986. The business of enting geti is a family business that has the potential as a producer and develops a center as a tourist village in Blitar Regency. The aim of SMEs Kuda Terbang is to maintain a hereditary business, as a source of family income, to preserve Blitar's special food and to introduce enting geti to be better known by the wider community. Supply Chain Structure of Enting Geti shown in Fig. 1.

Farmer: Farmers in the supply chain enting geti are coconut sugar farmers. Location of sugar farmers is found in Ndayu Village, Nglegok District, Blitar Regency. Farmers carry out postharvest processing and sell to collectors. Coconut sugar farmers will provide information to sugar distributors regarding the availability and quality of sugar. The price of sugar is determined by the agreement between the farmers and the sugar distributor. The risks faced by farmers in the supply chain are the low availability of sugar of good quality. Sugar availability in farmers is affected by erratic weather conditions. According to Lobell et al. (2008), climate with regional variability is a major determinant of agricultural production. When climate conditions change, production conditions also tend to change with positive or negative implications for agricultural production. Rainfall is the most dominant climate element for plants. Somawiharja et al. (2018), climate change will affect the quality of coconut sap and produce low quality coconut sugar. During storage, it is known that environmental factors (temperature, humidity, light and weather) influence the quality of the final product (de Aguiar et al., 2015).

Distributor: Distributors in the supply chain enting geti act as providers of brown sugar which has links with farmers and small traders. The distributor will pay to the sugar farmers at an agreed price. Sugar that has been purchased by distributors will be resold to small 
traders, with a flow of information in the form of price, quality and availability of sugar. Determination of the selling price of sugar to small traders is done by distributors based on the availability of sugar and market conditions. The owner of a sugar distributor named Mr. Ahmad, located in Pasar Ngentak, Nglegok District, Blitar Regency. The risk faced by the distributor is the low availability of sugar. What makes the distribution process and management complicated is the presence of uncertainty throughout the supply chain and in each stage. This form of uncertainty is in the form of low quality raw materials, misinformation and information delays. $\mathrm{Ng}$ and Chung (2008) stated that, distributors need to provide fast delivery services with small orders to meet the high availability requirements of downstream companies by providing delay services to partners in the supply chain. Furthermore, as stated by Fausayana et al. (2018), procurement stage of raw materials in sugar processing business is categorized high risk.

Importers: Importers in the supply chain enting geti act as providers of raw materials for peanuts and sesame for traders. Both raw materials are obtained from India. Importers provide information on prices of peanuts and sesame a few days before the trader makes an order. In addition to pricing information, importers will provide information regarding delays in shipping to traders in the event of delays due to delays in the distribution process. Risks faced by importers are price fluctuations and delays in the supply of peanuts and sesame. Kisaka and Mwasaru (2012), variations in exchange rates have implications for the entire economy including financial intermediaries and investors. Companies that are highly dependent on import activities will be affected by exchange rate variability.

Mercandhise/Traders: Traders in the supply chain enting geti are traders of raw materials for sugar, peanuts and sesame. There are two traders in the supply chain, namely:

Sugar trader: Sugar traders, with the owner $\mathrm{Bu}$ Mashita, are traders or small collectors selling at the Market. The flow of raw materials in this chain is that traders buy sugar at the distributor and sell it back to SMEs Kuda Terbang. When making an order, SMEs Kuda Terbang gives information on the number of orders and the type of sugar needed for production. The flow of information provided by traders to SMEs Kuda Terbang is the availability and price of sugar. The risk faced by sugar traders is the low availability of sugar with the quality desired by the producer. According to Samsudeen et al. (2013), rain positively affects sap production as seen from the higher production of sap during the rainy season. If there is a dry season, then the quantity of water is little but has good quality to be cooked into sugar. During the rainy season, the juice of the juice produced is much but the quality of the sugar produced is not good because the juice of the sap has been mixed with rainwater.

Peanut and sesame trader: Merchants of peanuts and sesame, namely Mrs. Malikah's shop located in Pasar Legi, Blitar City. Traders buy peanuts and sesame at importers located in Surabaya and Jakarta. The information that Mrs. Malikah gave to SMEs Kuda Terbang was related to the increase in raw material prices. When making a purchase, SMEs Kuda Terbang provides information about the specifications of the bean and the amount needed for the trader. Risks faced in this chain are fluctuating prices of peanuts and sesame. Widyastuti et al. (2018), the production process in business will run smoothly if the company has adequate raw material availability. Patel and Vyas (2011), the management of raw materials aims to ensure the material is available at the point of use when needed. The system ensures that the quality and quantity of the right material, the right time and the right price.

SMEs Kuda Terbang: SMEs Kuda Terbang in the supply chain has a role as a producer that buys raw materials, conducts the processing of these raw materials into essential products and distributes products to retail stores. After carrying out the production process, SMEs Kuda Terbang sent products to retailers in several areas in East Java to be marketed. Number of products sent by SMEs Kuda Terbang based on requests from the retailer. The risk faced by SMEs Kuda Terbang is a delay in production due to the availability of raw materials. Production delay caused by the lack of availability of raw materials resulting in the uncertainty of the SMEs Kuda Terbang production schedule. Other risks faced are processing, there are several processes that need to be controlled because they can affect the quality of the final product, namely the process of heating peanuts and cooking brown sugar. Kumar et al. (2012), production is the process of combining various inputs of material and material from production so as to produce output for consumption. In production, quality becomes important to pay attention to. According to Gurnani (1999), quality has been identified as a competitive strategy to improve business performance in the global market. Risk in the production challenge industry and businesses with regards to the quality of coconut sugar as and export material, an unacceptable quality is deemed to be unsafe to the consumers (Aquino et al., 2015).

Retailer: Retailers in the supply chain enting geti act as a store that sells several products including geti from SMEs Kuda Terbang. Activities carried out by retail stores are ordering products regularly and selling products to consumers. The risk that often occurs in retailers is the return of products (returns). Product 
Adv. J. Food Sci. Technol., 17(2): 18-27, 2019

Table 3: Value of FRPN for raw materials

\begin{tabular}{llllll}
\hline Risk & RiS & RiO & RiD & FRPN & Category risk \\
\hline Low availability of raw materials & 5.55 & 2.88 & 5.25 & 4.41 & Low-Moderate \\
Late supply of raw materials & 5.80 & 4.88 & 4.00 & 4.84 & Moderate \\
Prices of raw materials are volatile & 5.00 & 5.63 & 6.50 & 5.67 & Moderate-High \\
Raw materials are not according to standards & 5.50 & 3.50 & 5.55 & 4.67 & Moderate \\
\hline
\end{tabular}

Table 4: Value of FRPN for production

\begin{tabular}{|c|c|c|c|c|c|}
\hline Risk & RiS & $\mathrm{RiO}$ & RiD & FRPN & Category of risk \\
\hline Damage to machinery and equipment & 7.80 & 4.00 & 5.00 & 5.71 & Moderate-High \\
\hline Contamination during processing & 4.73 & 5.00 & 5.40 & 4.72 & Moderate \\
\hline Uncertain production schedules & 7.80 & 6.00 & 5.80 & 6.78 & High \\
\hline Fluctuating production capacity & 3.40 & 3.00 & 2.60 & 3.03 & Low \\
\hline Low quality products $\mathrm{h}$ & 8.73 & 4.00 & 3.40 & 5.31 & Moderate \\
\hline Damage to packaging during storage & 7.53 & 3.00 & 5.40 & 5.35 & Moderate \\
\hline The diversity of product prices in one center & 4.60 & 6.00 & 5.00 & 5.06 & Moderate \\
\hline \multicolumn{6}{|l|}{ Table 5: Value of FRPN for product } \\
\hline$\overline{\text { Risk }}$ & RiS & $\mathrm{RiO}$ & RiD & FRPN & Category of risk \\
\hline Fluctuating demand & 4.50 & 4.00 & 6.70 & 5.35 & Moderate \\
\hline Competitors of similar products & 6.60 & 5.50 & 3.70 & 4.85 & Moderate \\
\hline Lack of product inventory & 4.77 & 5.25 & 3.60 & 4.23 & Low-Moderate \\
\hline Delay in product delivery & 6.00 & 4.00 & 6.60 & 5.90 & Moderate-High \\
\hline Product returns & 8.00 & 5.25 & 6.60 & 6.83 & High \\
\hline
\end{tabular}

returns that occur at retail stores to SMEs Kuda Terbang are caused by damaged products, products that are approaching expiration and packaging that is not good. According to Mollenkopf et al. (2007), for managers, product return management is very important because product returns affect the profitability of the company and customer relationships

Consumers: Consumers in the supply chain are acting as buyers of essential products. Shirai (2015), as consumers usually prefer to get high quality products at lower costs. Consumers get essential products by buying products at retailers located in several regions in East Java. In addition, consumers can also buy products directly from producers in the SMEs Kuda Terbang shop. Consumers buying enting geti products at SMEs Kuda Terbang shop are consumers who are traveling in the center of enting geti.

Risk assessment using the Fuzzy FMEA method is done by calculating the value of FRPN (Fuzzy Risk Priority Number). According to Kutlu and Ekmekçioğlu (2012) the advantages of using the fuzzy FMEA method are enabling conduction of risk evaluation that is accommodating the uncertainty of information held to be more consistent and priority information based on expert knowledge. The input used for calculating FRPN values is data from expert respondents. According to Parsana and Patel (2014) the assessment of the severity aims to calculate how much effect is caused by the risk event The value of FRPN is divided into 3 based on the variables used, namely raw materials, production and products. Based on the FRPN value obtained then Ranking of each risk, where the top Rank is the largest FRPN value as a potential risk that needs attention. The results of the calculation of the FRPN value of the variables of raw materials, production and products can be seen in Table 3 to 5 .
Based on Table 3, the risk that has the highest rating is the fluctuating price of raw materials with FRPN 5.67 and included in the Moderate-High category. The rise and fall of the prices of raw materials for peanuts and sesame are influenced by market conditions and fluctuations in the dollar value. In the sugar raw material is affected by the availability of sugar to the distributor due to the uncertain weather, if there is a supply of raw material prices will fall and vice versa. The volatility of raw material prices will cause the production process to be hampered at SMEs Kuda Terbang with poor financial management conditions. These conditions can lead to several other risks, namely the delay in the production process, the low quality of the product and the determination of the selling price of the product. According to Alao and Oloni (2015), the implications of price fluctuations, no matter how small or large, will directly affect the price of goods produced and services provided. According to Supriyanto and Masruchah (2008), the purchase of materials at too high prices results in an increase in production costs which can then reduce the company's profits. Price fluctuations should be taken account because it affects profits gained in the supply chain structure (Abdulla et al., 2016).

Risk with the lowest FRPN value is the risk of low availability of raw materials with a value of 4.41. In raw materials for peanuts and sesame, suppliers tend to always provide raw materials because peanuts and sesame are imported. When inventory is low, suppliers immediately purchase raw materials so that stock is always available. In sugar raw materials, sugar availability is affected by weather conditions. During the rainy season, the sugar produced sometimes does not meet the standards of sugar needed for essential sugar production. But when the sugar that is needed is not available, SMEs Kuda Terbang uses different 
quality sugar raw materials that are available by small traders so that the company can still fulfill the demand. According to Gornall et al. (2010), agriculture is strongly influenced by cuca and climate. Climate change will have an impact on agriculture and potentially threaten the established aspects of the agricultural system. Stevenson (2002), to anticipate ingredients that are produced seasonally, there is a need for inventory, so that it can be used if the material is not in the market. Because of its seasonal nature, this applies to goods from nature or agricultural products.

Based on Table 4, the risk with the highest rating is the risk of uncertain production schedules. The uncertain risk of production schedules has an average value of fuzzy severity rating of 7.80, fuzzy occurrence of 6.50, fuzzy detection of 5.80 and a FRPN value of 6.78 in the High category. An erratic production schedule at SMEs Kuda Terbang is marked by a delay in the schedule for the production of ienting geti. The condition of raw material prices that rose quite dramatically caused SMEs Kuda Terbang could not supply raw materials. The lack of supply of raw materials can lead to losses when there is more demand for interest but SMEs Kuda Terbang does not have a supply of raw materials for production. According to Suryaningrat et al. (2003), clothing material is the most important factor to maintain processing activities in the agro-industrial system. According to Leyn et al. (2016), less optimal production scheduling resulted in several orders being delayed and unable to meet the deadline set by the customer.

Fluctuating production capacity is a risk with the lowest FRPN value of 3.03. This risk has an average value of fuzzy severity rating of 3.40, fuzzy occurrence 3 and fuzzy detection 2.60. SMEs Kuda Terbang in making essential production is based on the availability of raw materials and retailer demand. Therefore, SMEs Kuda Terbang's production capacity will adjust to the amount of raw material and demand. Aarabi and Hasanian (2014), capacity planning relates to ensuring a balance between requests submitted for operations and their ability to fulfill these requests.

Based on Table 5, the risk with the first rank is the risk of product returns. This risk has an average value of fuzzy severity 8 rating, fuzzy occurrence 5.25 , fuzzy detection 6.60 and a FRPN value of 6.83 with a High rating. Product returns from retailers to SMEs Kuda Terbang occur due to damage to the packaging and products that have approached the expiry date. Product returns result in reduced product sales volume on the part of retailers due to low product availability. In addition to affecting the image of the SMEs Kuda Terbang, product returns have resulted in SMEs Kuda Terbang returning to the retailer's demand. Xiuli et al. (2012), product defects are at the core of the obligations of modern products based on strict responsibilities.
The risk with the lowest FRPN value is the risk of product inventory deficiency. The risk has a FRPN value of 4.23 . The risk of a product inventory shortage occurs at the retailer due to an increase in demand but the availability of low-value products and differences in the number of requests from retailers with market conditions. This risk does not have a big impact because when supplies are important at low retail stores, the retailer then re-orders. In addition, retailers are also able to detect market conditions, so that when entering the holiday season retail stores already have important stocks. de Azevedo et al. (2014), uncertainty occurs due to varying and uncertain requests in number and time of arrival, manufacturing time which tends to be constant between one product and the next, lead time which tends to be uncertain due to many factors can't be controlled. This uncertainty can be suppressed by holding inventories. According to Stevenson (2002), inventory allows companies to support customer service, logistics, or circumstances where the purchase or manufacture of goods cannot meet demand.

The existence of research on risk mitigation in industrial products is currently very important to strengthen supply chain management. system of Food supply chain and the model of quality system of Food supply chain, to explore and discuss the risk of the supply chain as well as the quality control mechanism. The supply chain of Food is a long chain, the safety risk of Food mainly comes from the supply chain of the main operation process (Liu, 2016). According to WHO, risk assessment is the scientific evaluation of known or potential adverse health effects resulting from human exposure to foodborne hazards. The definition includes quantitative risk assessment, which emphasizes reliance on numerical expressions of risk and also qualitative expressions of risk, as well as an indication of the attendant uncertainties (Sani et al., 2013) and was application in Hu et al. (2017).

The research conducted by Rohmah et al. (2015) on Risk Measurement of Supply of Organic Rice Product Chain using Fuzzy Failure Mode Effect Analysis to explain the condition of organic rice supply chains with risk priorities from FRPN ratings are product return risk, risk of damage or loss of quality in the product, risk of contamination during the production process and risk of inventory shortages. Strengthened by Sarpong et al. (2013) used the FMEA method to identify, assess and evaluate various risk categories in the cocoa supply chain in the Ashanti Region, Ghana. The results of this study indicate that cocoa price volatility and interest rate volatility are the main market risks in the cocoa supply chain.

The formulation of alternative strategies is used to minimize supply chain risk by using the AHP method. AHP calculation is carried out based on a questionnaire given to two expert respondents, namely 1 person from SMEs Kuda Terbang and 1 expert from academia. 


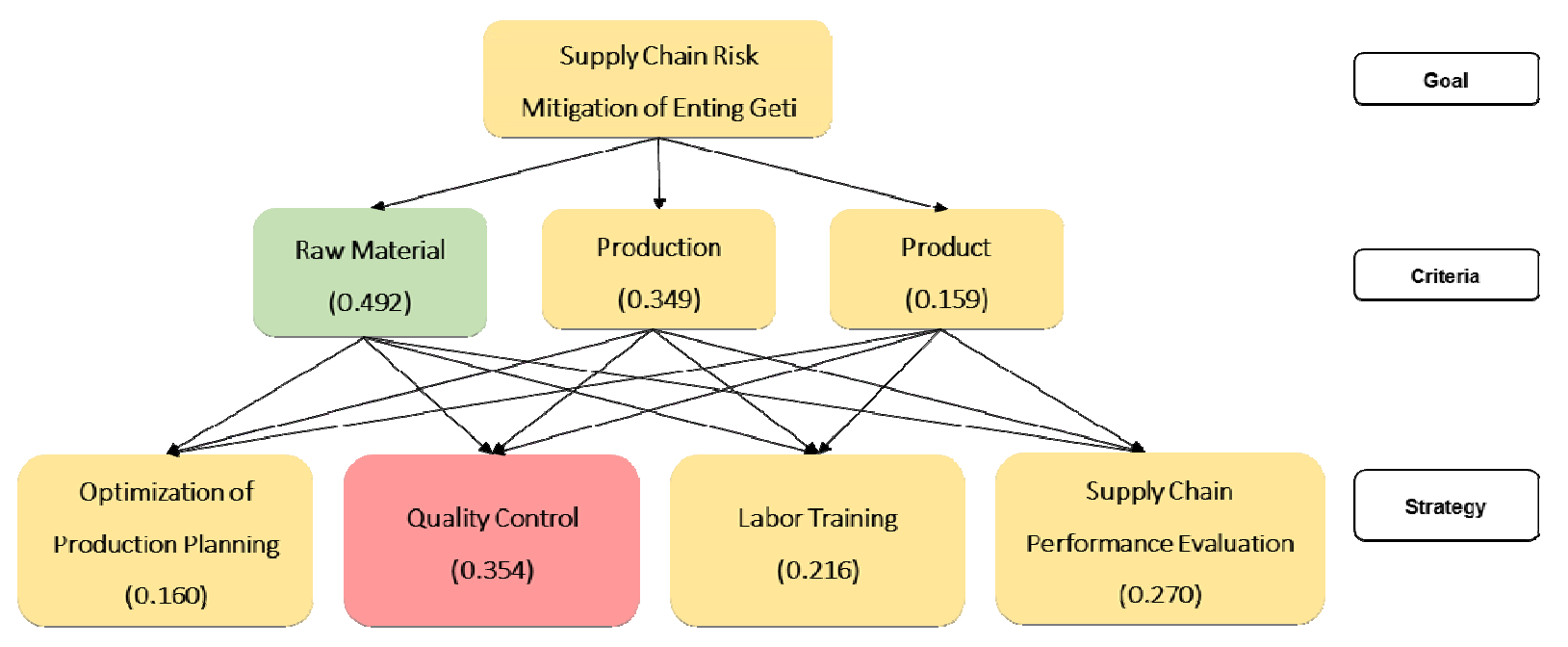

Fig. 2: Alternative hierarchy of supply chain risk mitigation strategies

\begin{tabular}{lll} 
Table 6: Consistency ratio for expert respondentt \\
\hline No. & Goal and criteria & Value of CR \\
\hline 1 & $\begin{array}{l}\text { Mitigation of risiko for supply } \\
\text { chain on enting geti }\end{array}$ & 0.028 \\
& Raw materials & \\
2 & Production & 0.046 \\
3 & Product & 0.069 \\
4 & & 0.025 \\
\hline
\end{tabular}

Making an alternative questionnaire on mitigation strategies is based on an alternative hierarchy of supply chain risk mitigation strategies which can be seen in Fig. 2.

In Table 6, the value of Consistency Ratio (CR) for the purpose of get supply chain risk mitigation is 0.028 , the raw material criteria is 0.046 , the production is 0.069 and the product is 0.025 . This value has fulfilled the consistency requirement which is $<0.1$ which means the data is valid and there is no need to re-fill the questionnaire. According to Arisusanty et al. (2018), Consistency Ratio (CR) is a parameter used to check whether the paired comparisons have been carried out consequently or not. The consistency value of the respondents is smaller than 0.1 which is a condition of AHP consistency, so that it can be said that it has fulfilled the requirements of being consistent in assessing criteria.

Based on Fig. 2, it can be seen that the criteria for raw materials have the greatest importance weight is 0.492 , the production criteria are 0.349 and the product criteria are 0.159 . Alternative strategy with the highest importance weight is quality control with a value of 0.354 . With regard to quality, SMEs Kuda Terbang has produced very interesting products with a bitter taste and colors that are too brown. Another risk is the return of products from retailers as a result of products that have been damaged and are approaching the expiration date. In addition to causing financial losses, these conditions can also lead to a decrease in consumer interest and trust in the importance of SMEs Kuda Terbang. According to Sidin and Wafa (2014), the importance of quality is in a dynamic environment. Quality has been identified as one of the competitive strategies to improve business performance in the global market. Budhatoki (2015), ineffective quality management will increase failure costs, maintenance and operating costs.

The alternative supply chain performance evaluation strategies have an importance weight of 0.270 . This strategy aims to anticipate risks that occur in suppliers such as fluctuating raw material prices. The risk of fluctuating raw material prices has caused SMEs Kuda Terbang to still have difficulties in obtaining raw material supply for the production process. Partners who supply a small amount of raw materials make SMEs Kuda Terbang difficult in selecting the cheapest raw material prices and the appropriate quality, so SMEs Kuda Terbang needs to add and establish supplier partners. According to Stevenson (2002), the main factor considered by a company when choosing a supplier is price, quality, service, location, supplier inventory policy and flexibility. Strategic orientation in supply chain management is an aspect of being competitive (Yeung, 2008) and trust has been shown as an asset for long-term partnerships (Cannon et al., 2010).

The labor training strategy alternative have a weight value of 0.216 . Manpower training is needed so that all activities related to production process activities can run well. During this time, the workforce that helped run the production came from family members of SMEs Kuda Terbang owners. However, when experiencing an increase in product demand, SMEs Kuda Terbang requires additional labor from local villagers. The new workforce has not yet gotten the knowledge related to enting geti production and so far SMEs Kuda Terbang has applied on the job training. Alipour et al. (2009), the aim of OJT training is to provide employees with specific task knowledge and skills in the workplace area. During this time, on the job 
training was carried out at a time when production was carried out with a large enough capacity when experiencing an increase in demand, it was less effective because workers who did not have knowledge and immediately worked would cause work accidents and cause obstacles to the production process. According to Vogt (2010), human factors are generally known in production, often the term human factor is limited to individual work experience, training, motivation and also related aspects of workplace ergonomics and physical working conditions. SMEs Kuda Terbang needs to apply job training to new workers before carrying out the production process to meet the high demand by making plans in advance.

The alternative optimization strategies for production planning have a weight value of 0.160 . Optimization of production planning at SMEs Kuda Terbang by conducting forecasting, raw material requirement planning and production scheduling. Effective long-term and short-term planning depends on forecasting essential products. The risk of fluctuating product demand makes SMEs Kuda Terbang need to forecast demand. SMEs Kuda Terbang has been forecasting demand with intuitive thinking or qualitatively, the company needs to forecast quantitatively. SMEs Kuda Terbang needs to supply raw materials with a stock of anticipation so that the company can do production when there is an increase in demand and an increase in raw material prices. Andersson et al. (2010), inventory control has the purpose of monitoring stock at a point in time. In addition, inventory control relates to stock maintenance and records advantages and disadvantages. Anticipation stock is an inventory to deal with predictable demand in the high demand season, but production capacity at that time was unable to meet demand. This inventory is also intended to maintain the possibility of the difficulty of obtaining raw materials so that it does not cause production to stop. The results of the systematic analysis demonstrated that risk management is a broad and complex subject, especially when its management aims to both avoid/minimize risk and guide the organization to a level where the risks can be transformed into competitive advantages (de Azevedo et al., 2014).

\section{CONCLUSION}

Risk identification of essential supply chain in SMEs Kuda Terbang consists of 4 risks that occur in the raw material variable, 7 risks that occur in the production variable and 5 risks that occur in the product variable. In raw material variables, the highest risk is the risk of fluctuating raw material prices with a FRPN value of 5.67. The highest rating risk for the production variable is an uncertain production schedule with a FRPN value of 6.78. In the product variable, the highest risk is the risk of returning the product with a FRPN value of 6.83 . The priority of the overall supply chain risk mitigation strategy at SMEs Kuda Terbang is to carry out quality control (0.354) to improve product quality. Priority of variable valuation with the highest weight value is the raw material variable (0.492).

\section{REFERENCES}

Aarabi, M. and S. Hasanian, 2014. Capacity planning and control: A review. Int. J. Sci. Eng. Res., 5(8).

Abdulla, W.G., U. Rianse, R.M. Iswandi, S.A.A. Taridala, L. Yunus et al., 2016. Mapping and preference of marketing risk of eco sweetener 'Aren Sugar'. Int. J. Environ. Sci., 1: 133-139.

Ambekar, S.B., A. Elbadbakar and V. Shrouty, 2013. A review: implementation of failure mode and effect analysis. Int. J. Eng. Innovat. Technol., 2(8): 37-41.

Aishah, T.N., J. Pyeman and R.M. Tajuddin, 2013. Integration of the internal Supply Chain Management (SCM) towards long run competitiveness. Management, 3(1): 12-15.

Alao, E.M. and E.F. Oloni, 2015. The effect of commodity price changes on firm value: Study of food and drinks service industry in Nigeria. Eur. J. Account. Audit. Finance Res., 3(6): 26-38.

Alipour, M., M. Salehi and A. Shahnavaz, 2009. A study of on the job training effectiveness: Empirical evidence of Iran. Int. J. Bus. Manage., 4(11): 1-6.

Andersson, H., A. Hoff, M. Christiansen, G. Hasle and A. Løkketangen, 2010. Industrial aspects and literature survey: Combined inventory management and routing. Comput. Oper. Res., 37(9): 15151536.

Aquino, A., M.G.A. Bautista, A. Bandala and E. Dadios, 2015. Color quality assessment of coconut sugar using Artificial Neural Network (ANN). Proceeding of the International Conference on Humanoid, Nanotechnology, Information Technology, Communication and Control, Environment and Management (HNICEM), pp: 15.

Arisusanty, D.J., Y. Arkeman, S. Rahardjo and D.A. Soeboer, 2018. Analysis on determining decision criteria of sea toll bait port using AHP method. ALBACORE, 2(1): 57-67.

Balubaid, M. and R. Alamoudi, 2015. Application of the Analytical Hierarchy Process (AHP) to multicriteria analysis for contractor selection. Am. J. Ind. Bus. Manage., 5: 581-589.

Behzadi, G., M.J. O’Sullivan, T.L. Olsen and A. Zhang, 2018. Agribusiness supply chain risk management: A review of quantitative decision models. Omega, 79: 21-42.

Budhatoki, D.K., 2015. Quality management: An effective approach to success. J. Nepalese Bus. Stud., 6(1): 87-90. 
Cannon, J.P., P.M. Doney, M.R. Mullen and K.J. Petersen, 2010. Building long-term orientation in buyer-supplier relationships: The moderating role of culture. J. Oper. Manage., 28(6): 506-521.

De Aguiar, C.L., A.L.B. Rocha, J.R. Jambassi, A.S. Baptista and R.B. Lima, 2015. Factors affecting color formation during storage of white crystal sugar. Focus. Modern Food Ind., 4(2015): 1-10.

De Azevedo, R.C., L. Ensslin and A.E. Jungles, 2014. A review of risk management in construction: Opportunities for improvement. Modern Econ., 5: 367-383.

Fausayana, I., W.G. Abdullah and Almunir, 2018. Identifying and mapping risks in the coconut brown sugar processing business. Adv. Agri. Botanics, 10(1): 1-8.

Felea, M. and I. Albăstroiu, 2013. Defining the concept of supply chain management and its relevance to Romanian academics and practitioners. Amfiteatru Econ. J., 15(33): 74-88.

Gornall, J., R. Betts, E. Burke, R. Clark, J. Camp et al., 2010. Implications of climate change for agricultural productivity in the early twenty-first century. Philos. T. Roy. Soc. B, 365(1554): 29732989.

Gurnani, H., 1999. Pitfalls in total quality management implementation: The case of a Hong Kong company. Total Qual. Manage., 10(2): 209-228.

Heckmann, I., T. Comes and S. Nickel, 2015. A critical review on supply chain risk-Definition, measure and modeling. Omega, 52: 119-132.

Hornibrook, S.A. and A. Fearne, 2003. Managing perceived risk as a marketing strategy for beef in the UK foodservice industry. Int. Food Agribus. Manage. Rev., 6(3): 1-24.

Hu, H., Y. Wu, X. Jin, T. Shu and H. Ruan, 2017. Quantitative risk assessment of Vibrio parahaemolyticus in Mytilus edulis in China. Adv. J. Food Sci. Technol., 13(2): 72-76.

Kisaka, S.E. and A. Mwasaru, 2012. The causal relationship between exchange rates and stock prices in Kenya. Res. J. Finance Account., 3(7): 121-130.

Kumar, P., K.V.M. Varambally and L.L.R. Rodrigues, 2012. A methodology for implementing total productive maintenance in manufacturing industries-a case study. Int. J. Eng. Res. Develop., 5(2): 32-39.

Kutlu, A.C. and M. Ekmekçioğlu, 2012. Fuzzy failure modes and effects analysis by using fuzzy TOPSIS-based fuzzy AHP. Expert. Syst. Appl., 39(1): 61-67.

Leyn, E., M. Yusuf and E.W. Asih, 2016. Production scheduling with Campbell Dudek smith and Gupta heuristic method. J. REKAVASI, 4(1): 10-15.

Liu, K., 2016. Study on risk and quality (safety) management mechanism of food supply Chain. Adv. J. Food Sci. Technol., 12(2): 97-100.
Lobell, D.B., M.B. Burke, C. Tebaldi, M.D. Mastrandrea, W.P. Falcon and R.L. Naylor, 2008. Prioritizing climate change adaptation needs for food security in 2030. Science, 319: 607-610.

Mollenkopf, D., I. Russo and R. Frankel, 2007. The returns management process in supply chain strategy. Int. J. Phys. Distrib. Logist. Manage., 37(7): 568-592.

Nakandala, D., H. Lau and L. Zhao, 2017. Development of a hybrid fresh food supply chain risk assessment model. Int. J. Prod. Res., 55(14): 4180-4195.

$\mathrm{Ng}, \mathrm{T} . \mathrm{W}$. and W. Chung, 2008. The roles of distributor in the supply Chain-push-pull boundary. Int. J. Bus. Manage., 3(7): 28-39.

Parsana, T.S and M.T. Patel, 2014. A case study: A process FMEA tool enhance quality and efficiency of manufacturing industry. Ind. Eng. Manage. Sci., 4(3): 146

Patel, K.V. and C.M. Vyas, 2011. Construction materials management on project sites. Proceeding of the National Conference on Recent Trends in Engineering and Technology.

Roghanian, E. and M. Fatemeh, 2015. Using fuzzy FMEA and fuzzy logic in project risk management. Int. J. Manage. Stud., 8(3): 373-395.

Rohmah, D.U.M., W.A.P. Dania and I.A. Dewi, 2015. Risk measurement of supply chain organic rice product using fuzzy failure mode effect analysis in MUTOS Seloliman Trawas Mojokerto. Agric. Agric. Sci. Proc., 3: 108-113.

Samsudeen, K., V. Niral, B.A. Jerard, M. Kumar, P. Sugatha and K.B. Hebbar, 2013. Influence of variety and season in the inflorescence sap production in Cocos nucifera L. J. Plantat. Crops, 41(1): 57-61.

Sani, N.A., S. Ariyawansa, A.S. Babji and J.K. Hashim, 2013. The risk assessment of Vibrio parahaemolyticus in cooked black tiger shrimps (Penaeus monodon) in Malaysia. Food Control, 31(2): 546-552.

Sarpong, K.O., O.F. Alexnder and E.K. Anin, 2013. An assessment of supply chain risks in the cocoa industry in the Ashanti Region, Ghana. Int. J. Humanit. Soc. Sci., 3(19): 191-201.

Shirai, M. 2015. Impact of "High Quality, Low Price" appeal on consumer evaluations. J. Promot. Manage., 21(6): 776-797.

Sidin, J.P. and S. Wafa, 2014. Quality management implementation and quality of production in Malaysia's manufacturing companies. Int. J. Res. Bus. Manage., 2(3): 53-60.

Somawiharja, Y., D.M. Wonohadidjojo, M. Kartikawati, F.R.T. Suniati and H. Purnomo, 2018. Indigenous technology of tapping, collecting and processing of coconut (Cocos Nucifera) sap and its quality in Blitar Regency, East Java, Indonesia. Food Res., 2(4): 398-403. 
Supriyanto, A. and I. Masruchah, 2008. Purchasing Guide. PT. Elex Media Komputindo, Jakarta.

Suryaningrat, I.B., V.M. Salokhe and P.A. Hicks, 2003. Fruit Processing in East Java: Challenges and Constrains. Food and Beverage, Asia.

Stadtler, H., 2008. Supply Chain Management: An Overview. In: Stadtler, H., C. Kilger and H. Meyr (Eds.): Supply Chain Management and Advanced Planning: Concepts, Models, Software and Case Studies. Springer Verlag, Berlin, Heidelberg, Germany, pp: 9-35.

Stamatis, D.H., 1995. Failure Mode and Effects Analysis-FMEA from Theory to Execution. Quality Press, New York.

Stevenson, J.W., 2002. Operation Management. McGraw Hill, New York.

Tang, C.S. 2006. Perspectives in supply chain risk management. Int. J. Prod. Econ., 103(2): 451-488.
Vogt, K., 2010. Human as an important factor in process production control. Proceeding of the 7th International DAAAM Baltic Conference Industrial Engineering, Tallinn, ESTONIA.

Wang, Y.M., K.S. Chin, G.K.K. Poon and J.B. Yang, 2009. Risk evaluation in failure mode and effects analysis using fuzzy weighted geometric mean. Expert Syst. Appl., 36(2): 1195-1207.

Widyastuti, W., N. Asandimitra and Y. Artanti, 2018. Inhibiting factors of inventory management: Study on food and beverage micro small and medium enterprises. Int. Rev. Manage. Market., 8(1): 64-67.

Xiuli, L., C. Baozhi and X. Hanqing, 2012. Study on principle of product defect identification. Proc. Eng., 43: 393-398.

Yeung, A.C.L., 2008. Strategic supply management, quality initiatives and organizational performance. J. Oper. Manage., 26(4): 490-502. 